Rabaska

Revue d'ethnologie de l'Amérique française

\title{
Essais sur Émile Nelligan et sur la chanson populaire
}

Volume 8, 2010

URI : https://id.erudit.org/iderudit/045259ar

DOI : https://doi.org/10.7202/045259ar

Aller au sommaire du numéro

Éditeur(s)

Société québécoise d'ethnologie

ISSN

1703-7433 (imprimé)

1916-7350 (numérique)

Découvrir la revue

Citer ce document

(2010). Essais sur Émile Nelligan et sur la chanson populaire. Rabaska, 8,

117-117. https://doi.org/10.7202/045259ar d'utilisation que vous pouvez consulter en ligne.

https://apropos.erudit.org/fr/usagers/politique-dutilisation/ 


\section{Place publique}

Points de vue / livre

\section{Essais sur Émile Nelligan et sur la chanson populaire}

Le professeur André Gervais de l'Université du Québec à Rimouski vient de faire paraître le « premier livre de Luc Lacourcière (1910-1989), pionnier au Canada de l'enseignement universitaire du folklore (1944) et pionnier au Québec de l'édition critique (1952) », vingt ans après la mort de son auteur. Rabaska a tenu à recueillir les points de vue de spécialistes sur cet ouvrage : ce sont ses collègues Benoît Lacroix, médiéviste, critique littéraire et ami de longue date de l'auteur, et André Gaulin, professeur émérite de littérature, qui l'a côtoyé à l'Université Laval; et les ethnologues Barry Ancelet, de l'Université de la Louisiane à Lafayette, qui a souvent échangé avec lui, Liliane Jagueneau et Marlène Belly, de l'Université de Poitiers, qui le connaissent de réputation. Leurs regards croisés donnent une vue d'ensemble très complète de cet ouvrage et forment en quelque sorte un hommage posthume à Luc Lacourcière à l'occasion du centenaire de sa naissance.

Luc Lacourcière Essais sur Émile Nelligan et sur la chanson populaire Édition préparée par André Gervais Montréal, Fides, 2009, 448 p.

ISBN 978-2-7621-2985-4

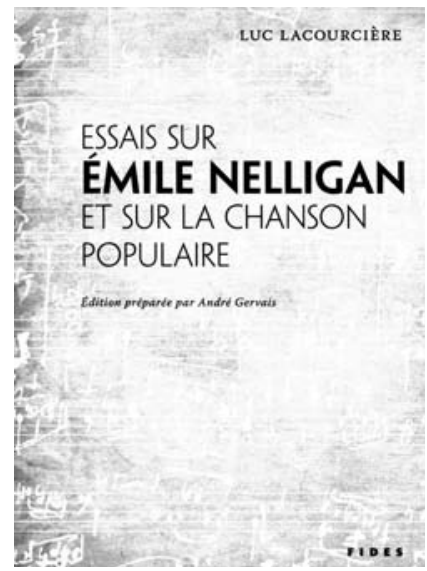

